\title{
Tonic spasms are a common clinical manifestation in patients with neuromyelitis optica
}

\author{
Espasmos tônicos são manifestações clínicas frequentes em pacientes com \\ neuromielite óptica
}

Luz Abaroa, Sergio A. Rodriguez-Quiroga, Luciana Melamud, Tomoko Arakaki, Nelida S. Garretto, Andres M. Villa

\begin{abstract}
Tonic spasms have been most commonly associated with multiple sclerosis. To date, few reports of series of patients with neuromyelitis optica and tonic spasms have been published. Methods: We analyzed the characteristics and frequency of tonic spasms in 19 subjects with neuromyelitis optica. Data was collected using a semi-structured questionnaire for tonic spasms, by both retrospectively reviewing medical records and performing clinical assessment. Results: All patients except one developed this symptom. The main triggering factors were sudden movements and emotional factors. Spasms were commonly associated to sensory disturbances and worsened during the acute phases of the disease. Carbamazepine was most commonly used to treat the symptom and patients showed good response to the drug. Conclusions: Tonic spasms are a common clinical manifestation in patients with neuromyelitis optica.
\end{abstract}

Key words: neuromyelitis optica, tonic spasms, secondary paroxysmal dystonia.

\section{RESUMO}

Espasmos tônicos têm sido mais frequentemente associados com esclerose múltipla. Foram publicados até agora poucos relatos de série de pacientes com neuromielite óptica e espasmos tônicos. Métodos: Foram analisadas as características e a frequência de espasmos tônicos em 19 indivíduos com neuromielite óptica. Os dados foram coletados por meio de um questionário semiestruturado para espasmos tônicos, mediante a avaliação retrospectiva dos prontuários e a análise dos dados clínicos Resultados: Todos os pacientes com neuromielite óptica exceto um apresentaram espasmos tônicos. Os principais fatores desencadeantes foram movimentos bruscos e fatores emocionais. Espasmos foram frequentemente associados a perturbações sensoriais e se agravaram durante a fase aguda da doença. A carbamazepina foi utilizada frequentemente para tratar os sintomas, com boa resposta. Conclusões: Os espasmos tônicos são manifestações clínicas frequentes em pacientes com neuromielite óptica.

Palavras-Chave: neuromielite óptica, espasmos tônico, distonia paroxística secundária.

Movement disorders (MD) have been observed in demyelinating diseases, especially in multiple sclerosis (MS ${ }^{1,2}$. Tonic spasms (TS), initially described by Matthews ${ }^{3}$, are the most common form of involuntary movements in $\mathrm{MS}^{1,4}$, occurring in 3.8 to $17 \%$ of these patients ${ }^{5}$. Tonic spasms are characterized by sudden onset of dystonic postures, either unilateral or bilateral, with typically short-lasting tonic attacks that, in certain occasions, are triggered by voluntary movements, sensory stimulation or hyperventilation. They can be preceded by a sensory, occasionally painful aura on the affected side or the contralateral side.

Anatomically, TS have been associated with different types of brain and spinal cord lesions. Although the pathophysiological mechanisms of this phenomenon remain unclear, the most widely accepted hypothesis is that stated by Osterman et al., describing them as occurring from axonal activation secondary to ephaptic cross-transmission in the demyelinated plaques at any level of the motor path ${ }^{6}$.

On the other hand, neuromyelitis optica (NMO) or Devic's syndrome is a disease that mainly affects the optic nerves and the spinal cord ${ }^{7}$. NMO can be distinguished from classical MS by clinical, neuroimaging, physiopathological and serological criteria $^{8-10}$. A new serum autoantibody (NMO-IgG) has been recently detected in NMO patients, thus becoming the first specific biomarker of an autoimmune central nervous system demyelinating disease ${ }^{11}$. To date, few series of patients with neuromyelitis optica and TS have been published, despite the clinical observation that these movements are usually reported by this group of patients. The aim of our study was to analyse the frequency and characteristics of TS in a series of patients with NMO in Argentina. 


\section{METHODS}

We evaluated 22 subjects with diagnosis of NMO that regularly attended the Neuroimmunology section of the Department of Neurology of the Hospital Ramos Mejía in the city of Buenos Aires, Argentina, from December 2006 to January 2011.

Three patients were excluded from the study because they were not able to go to the hospital for examination. We reviewed the clinical records of all patients, completed a neurological exam and performed a semi-structured questionnaire to find TS-compatible signs and symptoms. All patients were evaluated by a MD (NSG) and MS specialist (AMV). We analyzed the temporal relation between spasms and the disease relapses, spasm location, form of dissemination, frequency and duration, triggering factors, the presence of auras, course and therapy response. Spasticity was graded using the modified Ashworth scale $^{12}$. Wingerchuk's diagnostic criteria were used for NMO diagnosis ${ }^{9}$. All subjects signed an informed consent form, and the study was approved by the Hospital's Institutional Review Board.

\section{RESULTS}

Of the total number of patients, 18 were women, median age at onset of disease was 39 years (range 24-58) and median time of follow-up was 7 years (range 2-15). All patients except one developed TS during the course of the disease. The patient without spasms had a benign form of disease. Demographic, clinical and pharmacological features of patients with TS are shown in Table.

Most spasms involved one side of the body or the lower extremities. Three patients also showed evidence of trunk, neck and face involvement. Dissemination to other parts of the body usually occurred in an ascending (caudal to rostral, distal to proximal) manner. In five cases, spasms remained localized in only one body segment.

The main triggering factors were sudden movements, especially after long rest periods, and emotional factors. In one patient, spasms were triggered by head flexion. Spasms were typically noticed in the morning after getting up from a seated or lying position, or at gait initiation. Eight patients also presented spasms spontaneously at rest during acute episodes of myelitis.

All patients except one presented sensory symptoms ("somesthetic aura") associated with the TS. These symptoms were most frequently described as an unpleasant and ascending burning pain. In most cases, they preceded the spasms, but were also reported during or after the spasms occurred. Four patients reported that during periods of disease remission they could feel an isolated aura not followed by the abnormal movement. Nine patients described TS of one limb associated to a somesthetic aura of the contralateral limb.

Coexisting spasms and hypotonia was observed in one patient during the spinal shock period of the myelitis, when pyramidal signs had not yet evolved.

Table. Demographic, clinical and pharmacological features in patients with neuromyelitis optica and tonic spasms.

\begin{tabular}{|c|c|c|c|c|c|c|c|c|}
\hline $\begin{array}{l}\text { Patient } \\
\mathrm{n}\end{array}$ & $\begin{array}{l}\text { Years of } \\
\text { disease }\end{array}$ & NMO-IgG & Involved area & $\begin{array}{l}\text { Presence } \\
\text { of sensory } \\
\text { symptoms }\end{array}$ & Triggering factors & $\begin{array}{c}\text { Exacerbation } \\
\text { of TS during } \\
\text { relapses }\end{array}$ & $\begin{array}{l}\text { Spasticity } \\
\text { (MAS) }\end{array}$ & $\begin{array}{c}\text { Response to } \\
\text { therapy }\end{array}$ \\
\hline 1 & 6 & $(+)$ & $\mathrm{HB}$ & Yes & Sudden mov./distress & Yes & 1 & $\mathrm{CBZ}(+)$ \\
\hline 2 & 4 & $(+)$ & $\mathrm{HB}$ & Yes & Sudden mov. & Yes & 1 & $\mathrm{CBZ}(+)$ \\
\hline 3 & 11 & $(+)$ & $\mathrm{LL}$ & Yes & Sudden mov. & Yes & 1 & $\mathrm{CBZ}(+)$ \\
\hline 4 & 10 & NA & $\mathrm{HB} / \mathrm{RLL}$ & Yes & Sudden mov./distress & Yes & 1 & $\mathrm{CBZ}(+)$ \\
\hline 5 & 4 & $(+)$ & LL & Yes & Sudden mov. & Yes & 1 & NO TREATMENT \\
\hline 6 & 4 & $(+)$ & LL & Yes & Sudden mov./distress & Yes & 1 & $\mathrm{CBZ}(+)$ \\
\hline 7 & 17 & $(-)$ & $\mathrm{HB}$ & Yes & Sudden mov. & Yes & 1 & $\mathrm{CBZ}(+)$ \\
\hline 8 & 10 & $(+)$ & LL/UL/FACE & Yes & Sudden mov. & Yes & 2 & $\mathrm{CBZ}(+)$ \\
\hline 9 & 9 & $(+)$ & $\mathrm{HB}$ & Yes & Sudden mov./neck flexion & Yes & 2 & NO TREATMENT \\
\hline 10 & 6 & $(+)$ & LL/UL/NECK & Yes & Sudden mov./distress & Yes & 2 & $\mathrm{CBZ}(\mathrm{AE}) / \mathrm{GBP}(+)$ \\
\hline 11 & 5 & NA & $\mathrm{HB} / \mathrm{NECK} / \mathrm{FACE}$ & Yes & Sudden mov. & Yes & 2 & $\mathrm{ACZ}(+)$ \\
\hline 12 & 7 & NA & UL/LL & Yes & Sudden mov. & Yes & 1 & $\mathrm{CBZ}(+)$ \\
\hline 13 & 14 & $(+)$ & LL & Yes & Sudden mov./distress & Yes & 1 & $\mathrm{CBZ}(\mathrm{AE}) / \mathrm{GBP}(+)$ \\
\hline 14 & 4 & $(+)$ & LL & Yes & Sudden mov. & Yes & 2 & $\mathrm{CBZ}(+)$ \\
\hline 15 & 7 & $(+)$ & UL/LL & Yes & Sudden mov. & Yes & 3 & $\mathrm{CBZ}(+)$ \\
\hline 16 & 8 & $(+)$ & UL/LL & Yes & Sudden mov. & Yes & 2 & $\mathrm{CBZ}(+)$ \\
\hline 17 & 14 & $(+)$ & LL & Yes & Sudden mov. & Yes & 2 & $\mathrm{CBZ}(+)$ \\
\hline 18 & 3 & $(+)$ & UL/LL & No & Sudden mov. & Yes & 2 & $\mathrm{CBZ}(+)$ \\
\hline
\end{tabular}

NMO-IgG: aquaporin-4-specific serum autoantibody; MAS: modified Ashworth scale; NA: not available; HB: hemibody; LL: lower limbs; RLL: right lower limb; UL: upper limbs; mov:: movements; AE: adverse events; CBZ: carbamazepine; GBP: gabapentin; ACZ: acetazolamide; (+): positive therapeutic response; TS: tonic spasms. 
In one patient, TS were the first clinical manifestation of the disease.

Spasms lasted from a few seconds to 2-5 minutes, and the frequency ranged from several times during the day to weekly or monthly episodes. Severity, frequency and duration of spasms worsened during the acute phase of the disease in all patients and completely disappeared during remission in only $25 \%$ of them. Sixteen of the 18 patients required pharmacological treatment for TS. Carbamazepine (CBZ) was used in doses raging from 100 to $600 \mathrm{mg}$ /day with excellent response. Most of the patients required dose increases during disease relapses. Two patients were treated with gabapentin (GBP) because of adverse events to CBZ. Acetazolamide was used in one patient with good results.

\section{DISCUSSION}

The pathophysiology of TS is unclear and has been a matter of debate. In 1968, Ekbom et al. ${ }^{13}$ first described the mechanism of transversely spreading activation of damage axons in fiber tracts of the spinal cord in MS. They attributed the association of sensory symptoms followed by contralateral tonic attacks to the diffusion of the ephaptic impulses from the spinothalamic to the corticospinal tracts. Matthews proposed an alternative explanation, that during a voluntary movement, when activation along the corticospinal tract reaches the demyelinated plaques, impulses are wholly or partially blocked, thus spreading to the neighboring axons ${ }^{14}$. The proximity of the demyelinated axons, without the intervening glial tissue, has been claimed to support the lateral spread of activation ${ }^{15,16}$. On the other hand, TS have been widely been recognized to be related to a localized inflamatory reaction rather than to chronic established areas of demyelination ${ }^{17}$.

Our observations in NMO fit with the notion that demyelination renders axons hypersensitive to minor insults and that the irritation of these damaged axons facilitates ephatic activation, provoking TS. Our study adds evidence supporting the idea that the inflammatory process might be playing a role enhancing axonal excitability, with the consequent aggravation of the spasms during the acute phases of this disease.

From an anatomical point of view, the fact that NMO mainly affects spinal cord, apart from optic nerves, suggests that the origin of the spasms occur at this level. In addition, the sequential appearance of sensory-motor symptoms supports the cross-activation mechanism between sensory and motor nerve fibers at spinal cord level'.

Tonic spasms could mimic the "flexor spasms" associated with spasticity, observed in lesions of the pyramidal tract; however, the occurrence of TS during the spinal shock period, the low grade of spasticity found in most of our patients, the presence of sensory symptoms and the significant response to antiepileptic drugs (AEDs) suggest the presence of other mechanisms.

Similarly to primary paroxysmal kinesigenic dystonias, spasms in this group of patients were usually short, triggered by movements and with good response to AEDs. During acute phases of the disease, they resembled the non kinesigenic forms of primary dystonias, with longer duration, present at rest and with less response to AEDs.

The remarkable response observed in patients who received carbamazepine and acetazolamide is consistent with previous reports ${ }^{4,17}$ and with the hypothesis that a dysfunction of ion channels is involved in the pathogenesis of the spasms probably facilitating ephaptic transmission ${ }^{4,16,17}$.

Despite abundant evidence linking TS and MS, only few reports have suggested their association with $\mathrm{NMO}^{8,18-20}$. Wingerchuk ${ }^{8}$ reported a TS incidence rate of $35 \%$ in patients with NMO (17 of 48 patients) and more recently, Usmani ${ }^{19}$ reported an incidence of $14 \%$ ( 8 of 57 patients). The occurrence of TS in our NMO case series was 95\% (18 of 19 patients). The higher incidence we observed compared to previous series could be mainly the result of the methodology employed to extract data and probably because of the long follow up period in most of our patients. While previous groups ${ }^{8,19}$ performed a retrospective review of medical records for documentation of TS, we also performed a directed questionnaire to each subject searching symptoms compatible with TS. On the other hand, the frequency of TS in NMO seems to be much higher than in MS, and this could be due to the different anatomopathological involvement of the spinal cord and the different behaviour of these diseases.

In conclusion, our results demonstrate that $\mathrm{TS}$ are a common clinical manifestation in patients with neuromyelitis optica.

\section{ACKNOWLEDGMENTS}

We thank the participating patients and Dr. Brandon Barton for his contribution in editing and traducing our material.

\section{References}

1. Tranchant C, Bhatia KP, Marsden CD. Movement disorders in multiple sclerosis. Mov Disord 1995;10:418-423.

2. Nociti V, Bentivoglio AR, Frisullo G, et al. Movement disorders in multiple sclerosis: causal or coincidental association? Mult Scler 2008;14:1284-1287.

\footnotetext{
3. Matthews WB. Tonic seizures in disseminated sclerosis. Brain 1958;81:193-206.

4. Waubant E, Alize P, Tourbah A, Agid Y. Paroxysmal dystonia (tonic spasm) in multiple sclerosis. Neurology 2001;57:2320-2321.
} 
5. Berger JR, Sheremata WA, Melamed E. Paroxysmal dystonia as the initial manifestation of multiple sclerosis. Arch Neurol 1984; $41: 747-750$

6. Ostermann PO, Westerberg CE. Paroxysmal attacks in multiple sclerosis. Brain 1975;98: 189-202.

7. Mandler RN, Davis LE, Jeffery DR, Kornfeld M. Devic's neuromyelitis optica: a clinicopathological study of 8 patients. Ann Neurol 1993;34:162-168.

8. Wingerchuk DM, Hogancamp WF, O'Brien PC, Weinshenker BG. The clinical course of neuromyelitis optica (Devic's syndrome). Neurology 1999;53:1107-1114.

9. Wingerchuk DM, Lennon VA, Pittock SJ, Lucchinetti CF, Weinshenker BG. Revised diagnostic criteria for neuromyelitis optica. Neurology 2006;66:1485-1489.

10. Wingerchuk DM, Weinshenker BG. Neuromyelitis Optica. Curr Treat Options Neurol 2005;7:173-182.

11. Lennon VA, Wingerchuk DM, Kryzer TJ, et al. A serum autoantibody marker of neuromyelitis optica: distinction from multiple sclerosis. Lancet 2004;364:2106-2112.

12. Bohannon RW, Smith MB. Interrater reliability of a modified Ashworth scale of muscle spasticity. Phys Ther 1987;67:206-207.
13. Ekbom KA, Westerberg CE, Osterman PO. Focal sensory-motor seizures of spinal origin. Lancet 1968;1:67.

14. Matthews WB. Pathophysiology of paroxysmal symptoms in multiple sclerosis. In: Mc Alpine's Multiple Sclerosis. Edingburgh: Churchil Livingstone; 1985. p. 217-219.

15. Prineas JW, Connell F. The fine structure of chronically active multiple sclerosis plaques. Neurology 1978;28:68-75.

16. Sozzi G, Marotta P, Piatti L, Taborelli A, Dorizzi A. Paroxysmal sensorymotor attacks due to a spinal cord lesion identified by MRI. J Neurol Neurosurg Psychiatry 1987;50:490-492.

17. Spissu A, Cannas A, Ferrigno P, Pelaghi AE, Spissu M. Anatomic correlates of painful tonic spasms in multiple sclerosis. Mov Disord 1999;14:331-335

18. Komolafe MA, Komolafe EO, SunmonuTA, et al. New onset neuromyelitis optica in a young Nigerian woman with possible antiphospholipid syndrome: a case report. J Med Case Reports 2008;2:348.

19. Usmani N, Bedi G, Lam BL, Sheremata WA. Association between paroxysmal tonic spasms and neuromyelitis optica. Arch Neurol 2012;69:121-124

20. Schmidt FR, Costa FH, Silva FM, et al. Paroxysmal dystonia and neuromyelitis optica. Arq Neuropsiquiatr 2012;4:271-273. 